\title{
Achievement Gaps in Education
}

\author{
Allan C. Ornstein
}

Published online: 4 August 2010

(C) Springer Science+Business Media, LLC 2010
1960 s, despite hundreds of task force reports and attempts for school reform, and despite thousands of compensatory programs and tens of billions of dollars spent annually on low-income and low-achieving students, our education system is in a state of depression. Although we can point to individual schools and school districts that are successful, our system as a whole has not improved.

Achievement gaps between Asian and white students compared to Hispanic and black students remain alarmingly high, and by 2015 the latter group of students will represent the majority enrollments. Comparatively U.S. students consistently score on achievement tests below students in other industrialized nations, despite the fact we spend more money per student on education than all the countries except Switzerland. The number of U.S. college students majoring in science, math and engineering are flat, and the percentage of graduates in these two essential areas in Western European and especially Asian countries have increasingly outpaced our nation.

The state of American education can be summed up by the report, A Nation at Risk, published more than 25 years ago, which indicated that a "rising tide of mediocrity" is eroding the well-being of the nation. This mediocrity is linked to the foundations of our educational institutions and is spilling over into the workplace and other sectors of society. The report listed several aspects of educational decline that were evident to educators and citizens alike: lower achievement scores, lower testing requirements, lower graduation requirements, lower teacher expectations, fewer academic courses, more remedial courses, and higher illiteracy rates. It noted that the schools have attempted to tackle too many social problems that the home and other agencies of society either will not or cannot resolve. The report called for tougher standards for graduation, more 
courses in science, mathematics and foreign language, a longer school day and school year, far more homework, improved and updated textbooks, more rigorous testing and higher expectations for student achievement, teacher accountability, higher salaries for teachers, and more rigorous certification standards for teachers.

The report was hailed by school administrators, policy makers, and business people as the most important government document published for and about educators and as the prescription for reform. The report could have been written in 2010 because almost nothing has changed; in fact, disappointingly it can be argued that conditions have worsened. H.G. Wells summed it up best: "History is a race between education and catastrophe." We are losing that race, and the odds of winning seem to worsen each year.

Although we can present a cascading number of facts and figures about our failure to achieve significant education progress, the idea in this article is to focus on the big picture and avoid scores of data. That said, after spending nearly half a trillion dollars on compensatory programs for low-income and low-achieving students, educators are still unable to determine which programs work and whether more spending affects educational outcomes. Obviously, other variables need to be considered, some which may be considered unpleasant or politically incorrect.

\section{The International Report Card}

Moving on to the demands of knowledge and technology, the data are not impressive when comparisons are made between U.S. students in math and science and students in advanced technological countries. European and Asian students consistently outperform American students on international tests in science and mathematics, and the gaps consistently increase in the higher grades.

The international comparisons started in the 1960s, with the International Association for the Evaluation of Educational Achievement (IEA), in areas of mathematics, involving 133,000 elementary and secondary students and 5,450 schools in twelve technologically advanced countries. [See Torsten Husen, International Study of Achievement in Mathematics: A Comparison of Twelve Countries, Vols. 1 and 2. (New York: Wiley, 1967).] Especially noticeable were the overall good showings of Japan and Israel and the poor showings of the United States. The range of difference between high and low performing countries decreased when the most able students were compared, indicating that the "cream of mathematics talent" is distributed equally over various countries. Student characteristics highly correlated with achievement, and the child's social class accounted for the greatest share of variation in learning. The study also showed that at every age level, and in most countries, boys outperformed girls.

In the next group of studies, the researchers embarked on a six subject survey, including science. In this study, 258,000 elementary and secondary students and 9,700 schools in nineteen countries (four of them undeveloped) were involved. U.S. students never finished first or second in any of the six subject areas and were last seven times; in science, they scored below the international average. Although the impact of the home was considerably greater than the direct effect of school variables, the impact of schooling was shown to be generally more important for science and foreign language than for other areas. The suggestion that certain subjects might be more amenable to school influences is encouraging to those who feel that schools should have a significant effect on learning. [See L.C. Comber and J.P. Keeves, Science Education in Nineteen Countries (New York: Wiley, 1973).]

As a matter of common knowledge among text experts, there are unique limitations with large-scale international studies, including common content across countries, translation of content and selection or representation of students to be tested. Nevertheless, international test comparisons have continued for the last 35 years. For this policy agenda, the international report card for U.S. students would be around a "D."

Fast forwarding to the most recent and famous international tests in mathematics and science are the Trends in International Mathematics and Science Study (TIMSS), administered three times in grades 4,8 , and 12 in 1995, 1999, and 2003. In the first two studies, published between 1998 and 2001, U.S. fourth grade students in math ranked eighth out of eighteen among industrialized countries that participated, and in science tied for third place. In eighth grade, U.S. students ranked slightly below average in math (twenty-three out of thirty-eight industrialized countries) and slightly above average in science (below fourteen countries). By the twelfth grade, American students scored last in math among twenty industrialized countries, and in science they scored below sixteen countries. While the international average math/science scores were 500, the U.S. average in math was 461 and in science 480 .

International test comparisons were so bleak that for the third study, the U.S. government decided to compare U.S. scores and relative ranking with all countries, including those from the third world and poorest parts of the world. Not surprisingly, U.S. math and science scores were reported average or above average by 
Newsweek, Time and the Wall Street Journal. The U.S. public was misled, pure and simple. For example, in 2003 science scores of fourth graders were seventh highest among 25 countries and eighth graders were twelfth highest among 44 other participating countries such as Armenia, Cyprus, Iran, Moldova, and Tunisia. What this proves is nothing of substance, since a hightech nation is being compared with low-tech nations. In mathematics the results were similar. Fourth graders ranked twelfth among 25 countries and eighth graders outperformed their peers twenty five out of 45 countries, including Bahrain, Botswana, Bulgaria, Egypt, and Jordon. Given the nature of the competition, the rankings for the U.S. don't hold much water and to some extent are meant to deceive U.S. tax payers who support the schools.

America's decline in human capital continues beyond the TIMSS studies. The Program for International Student Assessment (PISA) reported in 2003 the mathematical literacy and scientific literacy skills of 15-year olds among 28 other industrialized countries and 10 nonindustrialized countries. U.S. students scored lower than twenty of the industrialized countries and three of the nonindustrialized countries in math and lower than nineteen of the industrialized countries and three of its nonindustrialized countries in science. The average U.S. math score was lower (483) than the average student performance of the 28 others industrialized countries (500). For science the average U.S. score was 491 compared to the average score (500). Further analysis of the data revealed that a greater percentage of U.S. students than the industrialized average scored at the lowest levels of performance in mathematics literacy and all four broad areas of problem solving. (No information on specific science topics was available in PISA 2003.)

In the most recent PISA test, administered in 2006, the U.S. 15-year olds ranked 25 lowest out of 30 in math and 24 lowest out of 30 in science among other industrialized countries. That put our average on the same level with Portugal and Slovakia, rather than with other industrialized countries such as Australia, Canada or South Korea. Of all the industrialized countries, the U.S. had the greatest percentages of students at or below the lowest level of proficiency in math and science, called level 1, "limited knowledge."

The International Adult Literacy and Lifeskills Survey (All) analyzed the degree to which the adult population could perform mathematical tasks in daily life and the work place. Specific areas of measurement included the ability to apply math skills to number sense, estimation, measurement and statistics. Six countries participated, including Switzerland, Norway, Canada, and Bermudaall which scored higher than the U.S.-and Italy.
Moreover, the Educational Testing Service has concluded that better educated people are leaving the workforce and being replaced by people with less education and skill. This trend reflects U.S. demographic changes - an increase in the minority population and a shift in the immigration policy.

For example, Hispanics scored $75 \%$ lower than whites and blacks score $63 \%$ lower. Native-born whites and Asian Americans were tied for second place in the international ranking in literacy. Immigrants account for $40 \%$ of the U.S. labor force, but they rank 74 points behind native-born immigrants. In short, American productivity is partially based on the G.I. Bill and pre-1960 immigrants who were largely from Europe and were more skilled than today's immigrants who hail from non European and non industrialized nations. Soon the more skilled workers will be retiring and replaced by a less literate workforce. The effect on productivity and global competition, and the subsequent economic decline of the country, can be predicted by referring to the logic of our demographic outcomes.

\section{The Economics of Schooling}

As the U.S. falls further behind in achievement, the McKinsey consulting firm released a report, The Economic Impact of the Achievement Gap in America's Schools in 2009. The implications of the report revealed our national decline in productivity and jobs. Had America been able to close the gap in science and math achievement between 1983 and 1998 and raised its performance to the level of such nations as Canada, Finland and South Korea, the U.S. Gross Domestic Product in 1998 would have been approximately $\$ 2$ trillion higher. If its achievement gap had been closed between black and Hispanic students and white and Asian students by 1998 the Gross Domestic Product in 2008 would have been about $\$ 400$ to $\$ 500$ billion higher. If the gap between America's low-income students and the remaining students had been similarly narrowed, GDP in 2008 would have been $\$ 400$ to $\$ 670$ billion higher. In terms of PISA math and science output and the amount of money we spend on each student, which is among the highest in the world, the report concludes that "we get $60 \%$ less for our education dollars in terms of average test score results than do other wealthy [industrialized] nations."

Classroom size or teacher-student ratios of a group contribute to student learning and ultimately to test outcomes. Obviously, one-to-one learning (a coach and student) is ideal and more effective than ten-to-one ratio of students to teacher, and this small group is more beneficial than a classroom size of twenty-five students. But the fact is social-class difference and racial 
difference (even when class is controlled) contribute to attitudes and behaviors related to learning. The U.S. average classroom size is 16 to 1 compared to Japan, South Korea, and Hong Kong where ratios are 19:1 to 28:1, yet the latter countries always outscore U.S. students in math and science tests.

The picture worsens when education spending is compared on an international level. Among industrialized countries reporting education spending, the United States spends only $3.5 \%$ of its GDP on education, ranking eighth among twenty industrialized countries. But our expenditures per student is higher-second only to Switzerland. In other words, other countries do not have same resources as we do, yet they make a greater effort by spending more of their GDP on education. The inference is that we do not get our money's worth in education spending - and money alone is not going to solve our education problems. To be sure, education is big business - and about $\$ 500$ billion is annually spent on K-12 education. However, there is little indication that spending more on schools will improve student achievement. The issue involves human capital-the values, motivation and work and study ethic of the nation and its youth.

There is a wealth of data over a 50-year period, starting with the 1966 Coleman report entitled Equal Educational Opportunity to the 2008 National Mathematics Advisory Panel report, Foundations for Success, showing that the most important variable related to student achievement is the child's family background and the second most important factor is the peer group. Other variables, including, what the schools or teachers do, "are secondary or irrelevant" in the words of Harvard's Christopher Jencks. In fact, there is data from Rand Corporation suggesting that no more than 17 to $20 \%$ of the variance related to student learning is associated with schooling and teaching. People with political motives would prefer to bury this data and hold teachers and schools accountable.

The point is, no person alive can say what education and social programs in schools have been consistently successful. Chapter by chapter, we have learned about the failure of one government program after another, including compensatory education, job training, urban renewal, and welfare-each of which cost tax payers billions of dollars a year. The analysis has suggested that with respect to school financing, we are already spending too much in terms of what we are getting in return. In the early stages of school and related compensatory programs, input increments have a high marginal return, but they gradually diminish as they are extended to large numbers of low-achieving children. Early gains fade out and there is virtually no increase in output; in fact in many areas of education we reach a "flat area," less output in relation to input, or worse, no return.

Sadly, nearly half of U.S. students who graduate high school test at the seventh grade level in math and eighth grade in science and one third below ninth grade in reading. Today's high school students are tomorrow's workforce. The effects of school achievement is seen in the erosion of America's global competitiveness-and future jobs which require skills that build on math and science literacy and reading. Business and military leaders complain that they are required to spend billions of dollars annually on costly remedial education and training programs in the basic skills, or the three Rs. Between 1980 and 2000, remedial mathematics courses in four-year colleges increased by $75 \%$, and, by 2000 , constituted one-fourth of all mathematic courses taught in these institutions. By 2005, more than 1.8 million, or $20 \%$ of, college students in two-and four-year colleges were enrolled in "learning strategies" courses-a euphemism for "remedial courses"-another 1.1 million or $12 \%$, were being tutored individually or in groups. As many as $25 \%$ of the recruits in the armed forces cannot read at the ninth-grade level. Teaching "learning strategies" and "study skills" has become a cottage industry at the high school, college, and armed service levels - what was once called "remedial education" before political correction entered the education area.

\section{Excuses and More Excuses}

So what excuses can U.S. educators muster to explain the consistently low scores of American students, despite concerted federal, state, and local efforts since the post-Sputnik era to increase math and science achievement scores. I promise to be brief. So here is the short list - enough to give you a buzz or a feeling of lightness or weightlessness, like the second before you are about to pass out or the instant you are above the diving board and gravity hasn't yet grabbed you.

1. About 20 to $33 \%$ of American middle school and high school science and math teachers are teaching out of license; furthermore, nearly half of those certified to teach science and math teach subjects they are not qualified to teach. (For example, a biology teacher may not be qualified to teach chemistry or physics and a math teacher may not be qualified to teach calculus (only algebra and geometry).

2. Since the mid 1950s there has been a slight average increase in science and math coursework among graduating U.S. high school students, 
leveling at 2.5 and 2.9 years respectively. But the data are not impressive when comparisons are made with high school seniors in other advanced countries. Japanese, South Korean, and Hong Kong high school students, for example, average $1 \frac{1 / 4}{4}$ science courses per year and $11 / 2$ math courses per year, including calculus and statistics. The result is that Japanese, South Korean and Hong Kong students consistently outperform American students on international tests.

3. Measuring the cumulative achievement on a short test may not sufficiently cover what students have learned. About $25 \%$ of the test items in math and science reflect topics not studied by American test takers.

4. American science and math textbooks are numeroussome above average, some average, some below average in quality-whereas textbooks in other counties are approved by the ministry of education so there is consistency of coverage. Our textbooks emphasize breadth of topics, to please a wide audience (15,000 different school districts) at the expense of depth of topics. As a result, American textbooks (and teachers who rely on these textbooks) foster superficial learning of a large body of information, while teachers of countries with a ministry have more time to teach students to think about procedures, to help students form hypotheses, make procedures, and acquire skills to conduct experiments and contrast ideas and findings.

5. American high school students have less homework (23\% of eleventh graders report no assigned homework, $14 \%$ do not do their homework, and $26 \%$ do less than 1 hour per day of homework), and engage in more social activities, out-of-school activities, and part-time jobs than their international counterparts who often have 4 to 5 hours of homework daily.

6. American students average 3.5 hours per day of TV viewing, not to mention Internet surfing, and we know there is an inverse relationship between TV viewing and student achievement, especially after the second or third grade. (The positive effects of watching Sesame Street and other language-skill programs become increasingly irrelevant after age seven or eight.)

7. European and Asian students have a longer school day and school year, with European countries averaging 200 days and Asian countries averaging 220 days, compared to the United States which has about a 180day school calendar.

8. Student poverty among American students is the highest, about 21 to $25 \%$. It is nearly $50 \%$ higher than in any other industrialized country; next is
Australia with $14 \%$ and Canada with $13.5 \%$. Moreover, we know poverty clearly correlates in an inverse relationship with student achievement. In addition, the United States has among the highest or highest student drug addiction, student violence, gang activity and teenage pregnancy among industrialized nations.

9. The breakdown of the American family is well documented. More than $50 \%$ of American students live with a single head of household; it approaches $75 \%$ in our big cities, where student achievement is the lowest compared in other parts of the country.

10. Finally, it should be assumed that the students taking the test in all countries are drawn from a normal bell curve or ability distribution. Some countries-such as China, Japan, and Russia - may have certain political agendas, or sensitivity about "saving face," and are more selective in determining which students will take the test. Moreover, if you eliminate black and Hispanic students from the test pool, American white students compare favorably with European nations and Asian American students compare favorably with Asian nations which score the highest in math and science tests.

[See Fred C. Lunenburg and Allan C. Ornstein, Educational Administration: Concepts and Practices, 5th ed. (Belmont, CA: Wadsworth, 2008), pp. 474-476.]

Although all of these reasons help explain the low scores in math and science achievement among American students on international test, part of the problem lies in the limited amount of course work in these twin subject areas. By way of example, if you want to learn how to drive, play tennis or chess, or read, you need to devote time to the endeavorthe more instructional time, the more proficient you should become. Thus, if Americans are concerned about math and science (and we should because of the informationtechnology age we live in), then we need to modify instructional time to allow for proficiency in these subjects. This consideration must be weighed against a belief among many educators that schools need to emphasize the whole child and the liberal arts, and that teachers should be paid on the basis of qualifications and experience with no differential for specific subjects such as math or science). Based on supply and demand, as well as the needs for the nation, free marketers would support higher pay for math and science teachers. In fact, in an era of high-stake testing, with most school districts focusing on reading and math achievement, there is concern among policy makers that science is getting shortchanged in the elementary and junior high schools.

While most of us recognize that spending money on education is an investment in the nation's future, pouring more money in schools scratches the surface of the larger problem of family structure and culture - which in turn deal 
with stratification and inequality. Society prepares the achievement gap before the students enter school; the poor and minority populations are the victims and the test results are the evidence that society is unfair and unjust.

Trying to break the cycle of poverty or target education reform seems hopeless on a larger scale. A few people will succeed in school, but the majority are doomed to failure because the so-called solution is isolated from the larger social and economic issues-basically inequality. According to Richard Wilkinson and Kate Pickett, British social scientists, in rich countries where incomes are more evenly distributed, the citizens have higher education achievement, live longer and have fewer rates of obesity and delinquency. In their book The Spirit Level, higher taxes on the rich and smaller difference in pay lead to a better quality of life for all the citizens of that country. Where inequality is greatest, the lower classes and those who feel discriminated perform worse on cognitive tests than in countries where there are fewer differences in socio-economic states. In a society that rewards individual achievement and innovation, it is argued that lower taxes cause people to work harder and the argument for more equality breaks down. But given the recent global economic meltdown, and the fact that a large percentage of the rich got their money by arrogance, theft and fraud, the idea of equality may sound less socialistic and more sympathetic to Americans. We all know what economic growth can do for us, but we also know that most people in the United States do not share in the nation's prosperity on an equal basis.

\section{Conclusion}

So where does all this leave us? What is saving America are not all the smart and rich people who graduated from Ivy League schools and wound up making millions on Wall Street. Actually, many of them helped cripple the American economy. What is saving us is "brain drain." What we need to do is encourage more talented immigrants to our shores to compensate for the over-all international failure of American students in science and math. The sad fact is that we have failed as a nation to achieve significant progress in science and math-and in remaking our schools. After 50 years of education failure, maybe it is time to think less about school-based solutions and more about the larger issues of inequality. Maybe it's time to rethink the free market, and what Warren Buffet once said that "only when the tide goes out do you find who is not wearing a bathing suit." Well, you don't have to be a star gazer nor believe in the oracle to understand that the tide of technology and economic competition is turning - and not in our favor.

Allan C. Ornstein is Professor of Administration And Instructional Leadership at St. John's University in New York. He received his Ed.D. from New York University and is author of more than 55 texts and 500 articles and research papers. 